\title{
The adults and preimaginal stages of continental populations of Cricotopus (Cricotopus) beckeri Hirvenoja (Diptera, Chironomidae)
}

\author{
M. Hirvenoja 1 \\ Z. Moubayed 2
}

Keywords : Cricotopus beckeri, description, systematic position, distribution.

The adults and preimaginal stages of Cricotopus (C.) beckeri Hirv. from northwestern Africa and south west of France are described. Some comments about the systematic position, ecology and distribution are given.

Les adultes et les stad es preimaginaux des populations continentales de Cricotopus (Cricotopus) beckeri Hirvenoja (Diptera, Chironomidae).

Mots clés : Cricotopus beckeri, description, position systématique, distribution.

Les adultes, l'exuvie nymphale et la larve de Cricotopus beckeri Hirv. de l'ouest de l'Afrique du Nord et du S-O. de la France sont décrits. Quelques commentaires sur la position systématique, l'écologie et la répartition de l'espèce sont donnés.

\section{Cricotopus (C.) beckeri Hirv.}

\section{IMAGO}

Cricotopus (C.) beckeri Hirv. was originally described from one pinned adult male and one female collected by Th. Becker from Madeira Island (Hirvenoja $1973 ; 206-208$ ).

From the Aissi River in northern Algeria specimens have been found which in many respects are similar to $C$. beckeri. The gonocoxite lobes, however, resemble more closely those of $C$. (C.) curtus Hirv, than those of $C$. beckeri from Madeira or $C$. (C.) triannulatus Macq. In both the latter species the antero-dorsal part of the gonocoxite lobes typically narrows towards the apex.

In addition the legs of the specimens from Madeira are unicolored and in the male specimen are seen only 5 sensillae chaeticae in the metatarsus of the hind leg. In the specimens of the Aissi River population the coloration of the scutum and that of the legs is paler than in the holotype of C. beckeri and furthermore the number of sensillae chaeticae is higher, 12-18.

1. Sotilaskorventie 13, SF-01730 Vantaa, Finland.

2. Sud-Environnement 15 , rue des Aiguerelles, 34000 Montpellier, France.
Some specimens recently found in southwestern France (Massane river, eastern Pyrenees) agree well with the population from Algeria described below.

To check the original description the second male specimen (paratype) from the Zoological Museum of the Humboldt University, Berlin, DDR, kindly sent by Dr. H. Schumann, was prepared and studied. Only 10 sensilla chaeticae were with certainty counted in the metatarsus of the hind leg, but in other respects the paratype agrees very well with the holotype. Palpal segments (2-5) were $65,100,115$ and $205{ }_{\mu} \mathrm{m}$ and those of legs (in ${ }_{\mu} \mathrm{m}$ ) as follows :

$\begin{array}{lrrrrrrr} & \mathrm{Fe} & \mathrm{Ti} & \mathrm{Ta} & \mathrm{Ta}_{2} & \mathrm{Ta}_{3} & \mathrm{Ta}_{4} & \mathrm{Ta}_{5} \\ & & & & & & & \\ \text { PI } & 760 & 955 & 610 & 325 & 240 & 175 & 115 \\ \text { PII } & 825 & 805 & 380 & 215 & 150 & 90 & 90 \\ \text { PIII } & 760 & 890 & 510 & 250 & 205 & 110 & 100\end{array}$

The continental form may even be a new species or a subspecies. Unfort unately the immature stages from the type locality (Madeira) are unknown, and we cannot on the basis of these adult specimens evaluate the taxonomical significance of the differences between the island and continental populations. 
Several species of the genus Cricotopus show similar morphological variability (cfr. figs. 86, 89, 92, 94 in Hirvenoja 1973). The relationships between the populations of $C$. beckeri can be seen as a phenomenon parallel to the population differences (?) in Halocladius $(H$.$) variabilis Staeg. (cf. Hirvenoja$ $1973: 119)$.

Results of the measurements of the Aissi River population from Arbâa des Ouacifs, alt. $310 \mathrm{~m}$ and Oued Djemâa, alt. $190 \mathrm{~m}$ follow :

$\sigma:(\mathrm{n}=5) A R$ 1.17-1.32. Chaetotaxy of head and thorax about as Fig. 118 in Hirvenoja (1973: 199). Palpal segments (2-5) 50-60, 100-115, 115-150, 210-225 ${ }_{\mu} \mathrm{m}$. Scutum not darkened. Wing 1.9-2.1 $\mathrm{mm}$ long. Sensilla chaeticae on $T a_{I}$, of $P_{I I I} 12-18$. $L R$ of $P_{I} 0.64-0.66, P_{I I} 0.47-0.49$ and $P_{I I} 0.57-0.59$. $B R$ in all legs not more than 2.8 . $T i$ with broad, unclearly pale rings. Legs in $\mu_{\mu} \mathrm{m}$ :

$\begin{array}{cccccccc} & \mathrm{Fe} & \mathrm{Ti} & \mathrm{Ta} & \mathrm{Ta} & \mathrm{Ta} & \mathrm{Ta} & \mathrm{Ta} \\ P_{I} & 695-760 & 955-1000 & 610-650 & 325-350240-260-175-185 & 115-125 \\ P_{I I} & 805-825 & 805-880 & 380-415 & 210-220 & 150-175 & 90-110 & 90-130 \\ P_{H I} & 740-770 & 870-945 & 510-545 & 245-280 & 205-220 & 110-120 & 100-115\end{array}$

The coloration and type of chatotaxy of the abdomen as is described from the holotype of $C$. beckeri. Hypopygium as in (Fig. 1).

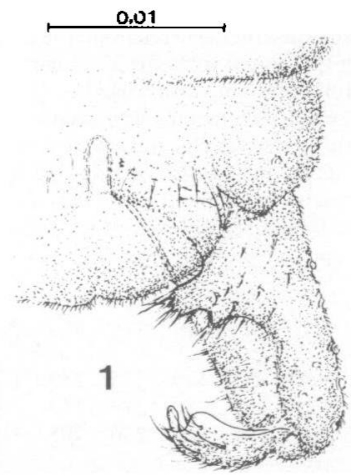

Fig. 1. - Cricotopus (C.) beckeri Hirv. - Hypopigium of a male from northwestern Africa. Scale $100 \mu \mathrm{m}$.

○: $(n=4)$ Coloration as in the male. Segments of the palps (2-5) 50-60, 80-105, 100-135 and 170-240 ${ }_{\mu} \mathrm{m}$ long. Wing length $1.7-1.9 \mathrm{~mm}$. More than 20 sensilla chaeticae on $P_{I I}$ and more than 26 on $P_{I I I}$.
$L R$ of $P_{I} 0.56-0.63, P_{I I} 0.44-0.49$ and $P_{I I} 0.52-0.59$. $B R$ in all legs not more than 1.8. Legs in $\mu \mathrm{m}$ :

$\begin{array}{cccccccc} & F e & T i & T a_{I} & \mathrm{Ta}_{2} & \mathrm{Ta}_{3} & \mathrm{Ta} & \mathrm{Ta} \\ P_{I} & 620-780 & 770-935 & 435-575 & 250-315 & 215-230 & 160-175 & 110-120 \\ P_{I I} & 585-805 & 650-850 & 315-370 & 165-200 & 135-150 & 90-110 & 85-100 \\ P_{I I} & 588-515 & 730-900 & 380-510 & 205-255 & 175-195 & 90-120 & 85-110\end{array}$

Seminal capsule with a short neck, about 105-125 ${ }_{\mu} \mathrm{m}$ long.

Pupa

Length of the exuviae: $\sigma^{\prime}, 4.3-4.5 \mathrm{~mm}$; $Q$, 4.0-4.1 mm. Cephalothorax and abdominal tergites, except the median parts of the last three segments somewhat darkened. Frontal apotome with 50-60 ${ }_{\mu} \mathrm{m}$ long cephalic tubercles (fig. 2), frontal setae absent. Thorax along the median suture crumpled and granulated. Thoracic horn (Fig. 3) spinulated, about $130_{\mu} \mathrm{m}$ long, and $<30_{\mu} \mathrm{m}$ broad. The chaetotaxy of the thorax and abdomen normal ; number of lateral setae on segments I-VII 1, 3, 3, 3, 3, $3,4,4$. Lateral dorsal seta $\left(d_{l}\right)$ of segment VIII usually but not constantly situating at the lateral border of this segment (seemingly 5 lateral setae !). Pedes spurii B on segments II and III. Segment I without shagreen, otherwise as in Fig. 4. Lobes of the anal segment (Figs. 5 and 6) somewhat pointed apically. Anal setae clearly shorter than a half length of the anal segment. The sheaths of the gonopods in the male as well as those of the cerci ending before tip of anal segment.

\section{Larva}

One larval skin with the head capsule was attached to the abdomen of a pupa. The details wholly agree with those of the larva of $C$. triannulatus described in Hirvenoja (1973: 185, 210-211). The details of the larve of $C$. beckeri have therefore not been illustrated here. The key on page 185 of the paper cited must be revised as follows ;

6 (4) Mandibelrücken gerunzelt .... triannulatus (Macq.) and beckeri Hirv.

Systematic position

In Hirvenoja (1973) the adult of $C$. beckeri was considered a member of the $C$. tremulus group because of the chaetotaxy of the abdomen and the structure of the hypopygium which are similar to the features in C. (C.) triannulatus (Macq.).

The characters of the pupa show some of the same relationships. In the exuviae the shagreen and chae- 
(3)

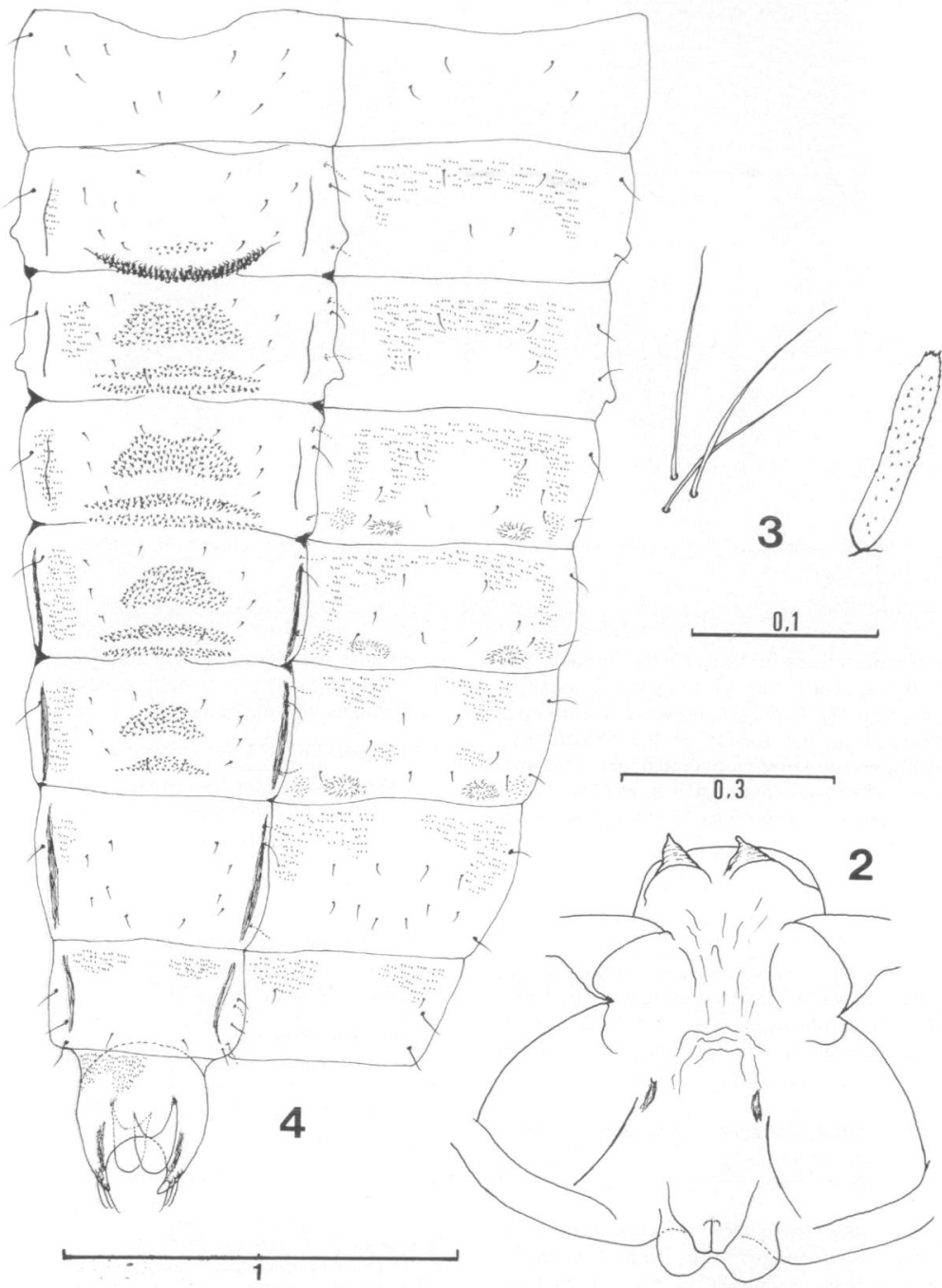

Fig. 2-4. - Cricotopus (C.) beckeri Hirv. - Pupa : head with cephalic tubercles (2), thoracic horn and necorneal setae (3) abdomen (4) showing the shagreen and chaetotaxy. Scales in mm. 

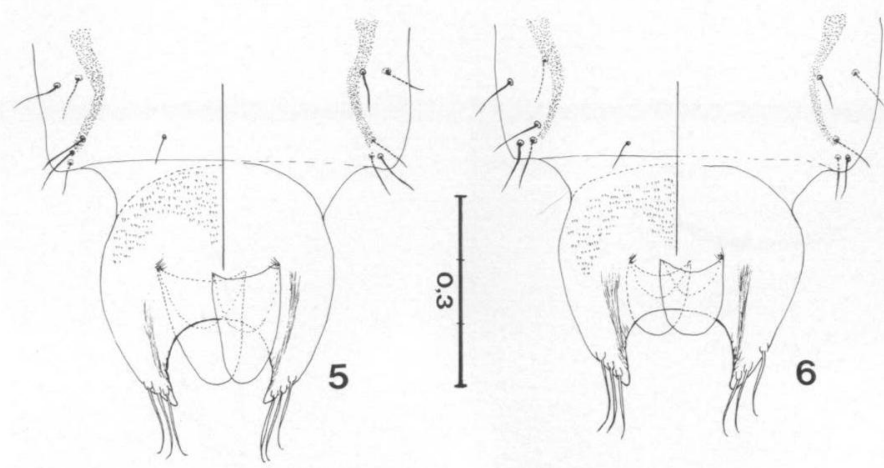

Fig. 5-6. - Cricotopus (C.) beckeri Hirv. - Pupa : anal segment of male (5) and female (6). Scale in $\mathrm{mm}$.

totaxy represent those in the C. tremulus group. The fourth lateral seta of the VIII segment is weak as in C. triannulatus. There are, however, features not common among the species of the Cricotopus: cephalic tubercles, somewhat pointed tips of the anal lobes, and shortened anal bristles as in Halocladius or Cricotopus (C.) levantinus Moubayed \& Hirvenoja (1986).

The couplets in the generic key for the pupae in Hirvenoja(1973:81) should be revised as follows :

3(4) fr-Borsten meist vorhanden, wenn sie fehlen, fehlt auch die starke Chagrinierung auf den Tergiten VII-VIII, auf Segment VIII sind $d_{7}$ und $l_{4}$ nicht gleich lang oder die Analflossenzipfel sind etwas verjüngt $\ldots \ldots \ldots \ldots \ldots \ldots \ldots \ldots \ldots \ldots \ldots \ldots \ldots \ldots \ldots \ldots \ldots$

5 (6) Frontalhöcker meist und fr-Borsten immer fehlend. Wenn Frontalhöcker vorhanden, so sind die Analflossenzipfel etwas verjüngt $\ldots \ldots \ldots \ldots 7$

The pupa differs clearly from the known species of the C. tremulus group (or of the genus Cricotopus) in having quite large cephalic tubercles on the frontal apotome and anal lobes pointed apically.
Because the larva is very similar to the larva of C. triannulatus the systematic position of $C$. beckeri can remain unchanged.

\section{DISTRIBUTION AND ECOLOGY}

Cricotopus beckeri is known from the western Mediterranian region : Madeira Island, southwestern France and northern Algeria. It represents one of the Tyrrhenian faunal elements essentially confined to the western subregion of the western Mediterranean. $C$. beckeri inhabits principally the rhithral of low mountain streams between 400 and 140 $\mathrm{m}$ altitude ; emergence occurs in May - June and in October - November.

\section{Aknowledgements}

Dr. D.W. Oliver read the manuscript and made valuable comments. We are indepted to Dr. Carol Norris for the English language correction.

\section{References}

Hirvenoja (M.). 1973. - Revision der Gattung Cricotopus van der Wulp und ihrer Verwandten (Diptera, Chironomidae). - Ann. Ent. Fenn. $10:$ 1-263.

Moubayed (Z.) \& Hirvenoja (M.). 1986. - Les Chironomides du Liban. IV. Cricotopus (Cricotopus) levantinus n. sp. (Diptera : Chironomidac, Orthocladiinae). Bull. Soc. Hist. Nat. Toulouse, $122: 169-173$. 